\title{
Effect of dairy cow genotype and concentrate feed level on cow performance and enteric methane emissions during grazing
}

\author{
Conrad Peter Ferris ${ }^{1}$, Hao Peng Jiao ${ }^{1}$, Stephen Murray ${ }^{1}$, Alan Gordon ${ }^{2}$ and Scott Laidlaw ${ }^{1}$ \\ ${ }^{1}$ Agri-Food and Biosciences Institute, Hillsborough, Co. Down BT26 6DR, United Kingdom \\ ${ }^{2}$ Agri-Food and Biosciences Institute, Belfast, Co. Antrim BT9 5PX, United Kingdom
}

e-mail: conrad.ferris@afbini.gov.uk

\begin{abstract}
The current study ( 40 cows in a $2 \times 2$ factorial arrangement) compared methane $\left(\mathrm{CH}_{4}\right)$ emissions from two dairy cow genotypes (Holstein-Friesian [HF], and Swedish Red $\times$ [Jersey $\times$ Holstein-Friesian] [Crossbred]) offered two levels of concentrate supplementation ( 3.0 or $6.0 \mathrm{~kg} / \mathrm{cow}$ per day) while grazing. Enteric $\mathrm{CH}_{4}$ emissions were measured using the $\mathrm{SF}_{6}$ technique on three occasions over a 16 week period, while intakes were estimated using performance data. Increasing concentrate level increased milk and energy corrected milk (ECM) yields, had no effect on $\mathrm{CH}_{4}$ emissions ( $g$ day ${ }^{-1}$ ) and $\mathrm{CH}_{4}$ emissions per kg dry matter (DM) intake, while reducing $\mathrm{CH}_{4} / \mathrm{ECM}$ yield. Crossbreds produced milk with higher milk fat and protein contents than $\mathrm{HF}$ cows, but ECM yield did not differ between genotypes. Daily $\mathrm{CH}_{4}$ production $\left(\mathrm{g} \mathrm{day}^{-1}\right)$, and $\mathrm{CH}_{4}$ production per kg ECM yield was unaffected by genotype. Methane yield $\left(\mathrm{g} \mathrm{kg}^{-1} \mathrm{DM}^{4}\right.$ intake) was higher with the Crossbred cows, although DM intake was estimated in this study, and this result should be interpreted with some caution. Thus $\mathrm{HF}$ and Crossbred cows had similar $\mathrm{CH}_{4}$ emissions.
\end{abstract}

Key words: dairy cattle, Swedish Red crossbreds, Holstein, greenhouse gases, SF6

\section{Introduction}

As concerns about climate change continue to grow, global pressure to reduce greenhouse gas (GHG) emissions has increased. Agriculture makes a significant contribution to global GHG emissions, with ruminant livestock systems known to be a significant source of emissions. For example, globally dairying accounts for approximately $21 \%$ of GHG emissions derived from the livestock sector, with $46 \%$ of these emissions attributed to methane $\left(\mathrm{CH}_{4}\right)$ derived from enteric fermentation (Gerber et al. 2013).

In recognition of this, much research has been undertaken to examine strategies by which to reduced $\mathrm{CH}_{4}$ production from dairy systems, with the use of 'genetic' approaches of particular interest. For example, $\mathrm{CH}_{4}$ production within individual animals of the same breed is known to vary (Pinares-Patiño et al. 2003). However, a small number of studies have examined if $\mathrm{CH}_{4}$ emissions from dairy cows of different genotypes also differ. For example, early studies compared $\mathrm{CH}_{4}$ production from different strains of Holstein cows (Gordon et al. 1995, Ferris et al. 1999), while a small number of studies have examined emissions from different dairy cow breeds (Münger and Kreuzer 2006, Yan et al. 2006). In addition, Xue et al. (2011) compared $\mathrm{CH}_{4}$ emissions from Jersey crossbred cows and pure bred Holstein cows. In general, major differences between genotypes have not been observed to date. However, these studies were undertaken using respiration calorimeters, and normally involved small numbers of cows of each genotype. In addition, these studies involved dairy cows offered conserved forage based diets.

Much less information is available on $\mathrm{CH}_{4}$ emissions from grazing cows of different genotypes. This is particularly important for crossbred cows which have a proven role within grassland based systems. Indeed, interest in crossing the Holstein-Friesian with alternative breeds, including the Jersey, has recently increased. While studies by Prendiville et al. (2009) and Vance et al. (2012a, 2013) have demonstrated that crossbreeding does not increase milk production, there is evidence of improved fertility (Vance et al. 2012a), health (Logue et al. 1994) and longevity (Touchberry 1992) with crossbred cows. In addition, there is evidence that crossbred cows have different grazing behaviours, and a higher intake/100 kg bodyweight (BW) compared to purebred Holstein cows (Prendiville et al. 2010, Vance et al. 2012b). More recently, research has examined the performance of 'threebreed' crossbred cows (Malchiodi et al. 2014, Ferris et al. 2018), with the benefits of adopting a three-breed cross breeding programme as a means of maximising hybrid vigour having been highlighted by Sørensen et al. (2008). These two studies both used the Swedish Red as one of the 'three breeds' within the cross, with anecdotal evidence suggesting that 'Scandinavian genetics' are increasingly being used within crossbreeding programmes within the UK. This interest in Scandinavian genetics can, in part, be attributed to the fact that historical sire selection programmes in these countries have been very different from those within most other countries, having incorporated fertility and health traits for several decades (Herringstad et al. 2000, Philipsson and Lindhe 2003). 


\section{AGRICULTURAL AND FOOD SCIENCE}

C.P. Ferris et al. (2020) 29: 130-138

Indeed, these very different selection programmes also raise the question of their impact on nutrient utilisation efficiency, including $\mathrm{CH}_{4}$ production, especially given differences in grazing behaviours observed with crossbred cows.

This study was funded by the government of the United Kingdom (UK) as part of a project designed to help improve the UK GHG inventory, and was designed to contribute information on emissions from grazing dairy cows, and from dairy cows of different genotypes. However, the data obtained allows us to further our understanding of $\mathrm{CH}_{4}$ emissions from dairy cows of two very different genotypes while grazing. It was hypothesised that $\mathrm{CH}_{4}$ production would differ between pure bred Holstein and Swedish Red crossbred cows. Thus the primary objective of this paper is to examine the effect of dairy cow genotype on $\mathrm{CH}_{4}$ emissions, within low and moderate concentrate input grazing systems, typical of those found within many grassland based regions of western Europe. Two different concentrate levels were adopted in this study as concentrate supplementation of grazing cows has been demonstrated to reduce $\mathrm{CH}_{4}$ emissions per $\mathrm{kg}$ of milk (Jiao et al. 2014).

\section{Materials and methods}

This experiment was conducted at the Agri-Food and Biosciences Institute (AFBI), Hillsborough, Northern Ireland $\left(54^{\circ} 27^{\prime} \mathrm{N} ; 06^{\circ} 04^{\prime} \mathrm{W}\right)$.

\section{Animals and experimental design}

This four treatment experiment $(2 \times 2$ factorial arrangement) involved forty dairy cows. Factors examined comprised two dairy cow genotypes, namely Holstein-Friesian (HF) and a three-breed crossbred (Crossbred) comprising 'Swedish Red $\times$ (Jersey $\times$ Holstein-Friesian)', and two concentrate feed levels (3.0 and $6.0 \mathrm{~kg} / \mathrm{cow}$ per day). The 20 cows of each genotype comprised 6 primiparous and 14 multiparous cows.

All cows used in the experiment were sourced from the Institute's dairy herd, which is a predominantly HolsteinFriesian herd. However, the Crossbred cows were the offspring of a breeding programme in which randomly selected HF cows from the herd were bred to Jersey sires (described previously by Vance et al. 2012a, 2013), with the offspring of this breeding programme subsequently bred to sires of the Swedish Red breed (described previously by Ferris et al. 2018). The HF cows had a mean pre-experimental milk yield of 29.5 (s.d., 6.69) kg day ${ }^{-1}$, and were 116 (s.d., 20.7) days in milk at the start of the experiment, while the respective values for the Crossbred cows were 27.8 (s.d., 4.44) kg day ${ }^{-1}$, and 113 (s.d., 23.2) days.

Cows were housed and offered grass silage based diets from calving (mean calving dates, 3 February and 7 February for HF and Crossbred cows, respectively) until late March, when grazing commenced, with full-time turnout achieved on 16 May. At this time (full-time turnout) cows were allocated to one of two concentrate treatments (10 HF and 10 Crossbred cows per treatment: 3 primiparous and 7 multiparous cows within each genotype), and concentrate levels adjusted so that they were offered either 3.0 or $6.0 \mathrm{~kg} / \mathrm{cow}$ per day at the start of the experiment on 30 May. Cows remained on these two concentrate treatments until the experiment ended on 18 September. Within each genotype, cows on each concentrate treatment were 'balanced' for lactation number, days-in-milk, and pre-experimental milk yield, bodyweight (BW) and body condition score (BCS).

The ingredient composition of the concentrate offered ( $\mathrm{g} \mathrm{kg}^{-1}$, fresh basis) was as follows: maize meal, 200; soya hulls, 197; milled wheat, 135; rapeseed meal, 135; maize gluten, 135: soyabean meal (Hi-Pro), 51; Molaferm (United Molasses, Belfast, UK), 88; Megalac (Volac Ltd. Orwell, Herefordshire, UK), 20; calcined magnesite, 10; palm oil blend, 7.5; salt, 7.5; limestone $\left(\mathrm{CaCO}_{3}\right)$, 7.0; trace minerals and vitamins, 7.0. Throughout the experiment the daily concentrate allocation for each treatment was offered in the milking parlour during milking, split between two equal meals.

\section{Grazing and grassland management}

Cows grazed perennial ryegrass based swards throughout the experiment. Once full time grazing was achieved, cows grazed within a rotational paddock grazing system (24-hour paddocks), with paddock size being 0.22 ha and 0.20 ha, for the treatments receiving 3.0 and $6.0 \mathrm{~kg}$ concentrate per cow/day, respectively. These different paddock sizes were adopted in an attempt to achieve similar pre- and post-grazing sward heights with both concentrate treatments (target $5.5 \mathrm{~cm}$ ), with this relatively high-post grazing sward height chosen so that herbage 


\section{AGRICULTURAL AND FOOD SCIENCE}

C.P. Ferris et al. (2020) 29: 130-138

intakes would not be restricted with either treatment. Cows were given access to fresh herbage daily, following afternoon milking.

Cows completed five grazing rotations during the course of the experiment with approximately 30, 25, 25 and 25 $\mathrm{kg}$ nitrogen $\mathrm{ha}^{-1}$ (in the form of calcium ammonium nitrate: CAN) applied following rotations 1-4, respectively.

\section{Cow performance}

Throughout the study cows were milked twice daily between 0600 and $0800 \mathrm{~h}$, and between 1600 and $1800 \mathrm{~h}$, with individual milk yields recorded automatically at each milking. During each $\mathrm{CH}_{4}$ measurement period (described below) milk fat, protein and lactose concentrations were determined on samples collected at each milking using a Milkoscan (Model FT 120, Foss Electric, Hillerød, Denmark). Cow BW was recorded after every milking with a mean BW calculated for each week. Body condition score was assessed fortnightly using a five point scale as described by Edmonson et al. (1989) (1 = emaciated; 5 = extremely fat).

\section{Measurement of methane}

Enteric $\mathrm{CH}_{4}$ emissions from all cows were measured during three separate measurement periods (18-22 June, 29 July-2 August and 10-14 September), using the sulfur hexafluoride (SF6) technique (Johnston et al. 2007). During each measurement period, emissions were recorded during five consecutive 24-hour periods. The permeation tubes used within this experiment contained approximately $2.4 \mathrm{~g}$ of SF6 gas when they were filled during March 2012 , and were incubated at $39^{\circ} \mathrm{C}$ until they were orally administered to cows on June 8 (10 days prior to the first experimental period). Prior to this, the release rate of $\mathrm{SF}_{6}$ from each permeation tube was determined via weekly gravimetric weighing over an eight-week period to produce an eight-point regression curve $\left(R^{2}>0.999\right)$. The mean release rate of $\mathrm{SF}_{6}$ from the permeation tubes at the start of the experiment was 4.29 (s.d., 0.85) mg day ${ }^{-1}$. In order to correct for the known decline in the rate of release of $\mathrm{SF}_{6}$ from the permeation tubes within the rumen during the course of the experiment, ten 'surveillance' tubes, with similar release rates as the tubes used within the experiment, were maintained at $39^{\circ} \mathrm{C}$ in an incubator and monitored weekly until six weeks after the completion of the final measurement period. The release rate of $\mathrm{SF}_{6}$ from the surveillance tubes was found to decline by $0.05 \%$ per day, and this value was subsequently used to adjust the individual release rates of each of the experimental tubes during periods 2 and 3, as described by Lassey et al. (2001).

On day-one of each of the three measurement periods, each cow was restrained within a head-locking gate, at approximately $1400 \mathrm{~h}$ (prior to evening milking), and fitted with a halter (to support the 'nose piece' and $\mathrm{CH}_{4}$ sampling line) and a Polyvinyl Chloride ( 2.5 litre) collection canister. The equipment was as described by Johnston et al. (2007), except that they regulated flow rate into the canister by inserting a stainless steel tube of given internal dimensions into the sampling line, while in the present study flow rate was regulated via a length (approximately $5.0 \mathrm{~cm}$ ) of capillary tubing (internal diameter, $0.1 \mathrm{~mm}$ : Alltech Associates, Lancashire, UK) which had been crimped at several points. Crimping was part of the calibration process necessary to achieve the correct flow rate which was measured using a digital flow meter (Cole-Parmer Instrument Co., Illinois, USA). Prior to the cow exiting the gate, the sample line was connected to the collection canister (which had previously been evacuated to over 900 mbar) using a quick connect fitting (Swagelok, Ohio, USA), thus allowing a gas sample to be drawn up into the evacuated canister at a rate of between 0.6 to $0.7 \mathrm{ml} \mathrm{min}^{-1}$ (approximately). The gas sample drawn into the evacuated canister was collected from the area around the cow's nostrils, and contained a mixture of normal atmospheric gases, $\mathrm{SF}_{6}$ and $\mathrm{CH}_{4}$.

At approximately $1400 \mathrm{~h}$ on the following day, cows were returned to the 'head locking gate', and the sample line removed from the canister. 'Used' canisters were replaced with 'new' canisters on day-2 to day-5 of each measurement period, while at the end of the final $24 \mathrm{~h}$ period, both the halter and canister were removed. On each day, used canisters were subsequently charged with nitrogen (a carrier gas) to a pressure of approximately $500 \mathrm{mbar}$, and analysed for concentrations of $\mathrm{SF}_{6}$ and $\mathrm{CH}_{4}$ by gas chromatography, as described by Johnston et al. (2007), using a Varian 3600 gas chromatograph (Varian Inc., Palo Alto, CA, USA). Background (ambient) concentrations of gases were measured during each $24 \mathrm{~h}$ period using four evacuated canisters attached to sample lines. Two of these were placed at each end of the two paddocks being grazed by the experimental cows, with the 'open' end of the sample line located approximately $40 \mathrm{~cm}$ above ground level. 


\section{AGRICULTURAL AND FOOD SCIENCE}

C.P. Ferris et al. (2020) 29: 130-138

\section{Feed sampling and analysis}

During each $\mathrm{CH}_{4}$ measurement period herbage pluck samples were taken daily from within the areas being grazed by each of the two experimental groups (at 20 random locations within each area at a height of approximately $5.0 \mathrm{~cm}$ above ground level). Each day one sub-sample from the grazing area for each treatment was analysed for metabolisable energy (ME) content using near infra-red reflectance spectroscopy (NIRS) as described by Park et al. (1998) (5 samples from each grazing area during each measurement period). A second sub-sample from each area was dried overnight at $85^{\circ} \mathrm{C}$ for dry matter (DM) determination and the dried samples subsequently bulked for each $\mathrm{CH}_{4}$ measurement period (one sample per grazing area per measurement period). Bulked samples were analysed for concentrations of $\mathrm{N}$, acid detergent fibre (ADF), water soluble carbohydrates (WSC) and ash. The concentrate offered during the study was sampled weekly, with the weekly samples bulked for each four-week period ( 5 samples over the experimental period). Concentrate samples were subsequently dried at $100{ }^{\circ} \mathrm{C}$ for 24 $\mathrm{h}$ for oven DM determination, while a second sample was dried at $60{ }^{\circ} \mathrm{C}$ for $48 \mathrm{~h}$, milled, and the dried samples analysed for N, ADF, NDF, ash and starch concentrations. Details of laboratory analysis used have been described previously by Purcell et al. (2016).

Sward heights were measured daily (pre- and post-grazing) throughout the experimental period using a rising plate meter (Jenquip, Feilding, New Zealand), with twenty sward-height measurements taken at random in a 'W' formation across each of the two paddocks being grazed.

\section{Herbage intake}

During each $\mathrm{CH}_{4}$ measurement period, herbage DM intake (DMI) for each cow was estimated from performance data, as described below. Milk energy content was determined from daily milk composition data using the equation of Tyrrell and Reid (1965), while mean daily BW change during each measurement period was determined by linear regression of weekly BW data for the four-week period prior to and including the $\mathrm{CH}_{4}$ measurement period. Total energy required was determined using the equations contained within 'Feed into Milk (FiM)', the UK dairy cow feed rationing system (Agnew et al. 2004), as the sum of energy required for maintenance, milk production, BW change, pregnancy (where appropriate) and activity. The ME content of the concentrate offered was assumed as $13.0 \mathrm{MJ} \mathrm{kg}^{-1} \mathrm{DM}$, based on published values (FeedByte, SRUC, Edinburgh, UK) for individual ingredients, with ME consumed from concentrate (MJ/cow/day) calculated as concentrate $\mathrm{DMI} \times 13.0$. The ME content of the herbage grazed was determined using NIRS, as described previously. Herbage DMI (kg day ${ }^{-1}$ ) was estimated by deducting 'ME consumed from concentrates' from 'total energy requirement', and dividing the remainder by the ME content of the herbage grazed.

\section{Statistical analysis}

Data from two cows (HF, $3.0 \mathrm{~kg}$; Crossbred, $6.0 \mathrm{~kg}$ ) were excluded from the analysis during all periods due to 'malfunction' of their permeation tubes. Data from a further cow (HF, $6.0 \mathrm{~kg}$ ) was excluded from period 1 due to mastitis, while another cow $(\mathrm{HF}, 3.0 \mathrm{~kg}$ ) was removed from the study on completion of period 1 due to mastitis. Data on animal performance, feed intake and $\mathrm{CH}_{4}$ emissions were analysed using repeated measures Residual Maximum Likelihood (REML) analysis. The mixed model used included the following terms as fixed effects: constant + period + Genotype + Concentrate level + period $\times$ Genotype + period $\times$ Concentrate level + Genotype $\times$ Concentrate level + period $\times$ Genotype $\times$ Concentrate level, while cow and cow within period were fitted as Random effects. Correlations between time points were modelled using an autoregressive model of order 1 . All data were analysed using Genstat 14.2 (Lawes Agricultural Trust, Rothamsted, UK).

\section{Results}

The concentrate offered had a mean ( \pm s.d.) crude protein, NDF, ADF, ash and starch content of $192(1.6), 297$ (4.7), 168 (3.9), 87 (2.7) and 249 (17.4) $\mathrm{g} \mathrm{kg}^{-1} \mathrm{DM}$, respectively. The mean ( \pm s.d.) pre- and post-grazing sward heights with the $3.0 \mathrm{~kg}$ concentrate treatment were $10.1(2.09)$ and $6.0(1.20) \mathrm{cm}$, respectively, while the respective values for the $6.0 \mathrm{~kg}$ concentrate treatment were $10.2(1.94)$ and $5.9(1.50) \mathrm{cm}$. Herbage offered with the $3.0 \mathrm{~kg}$ concentrate treatment had a mean ( \pm s.d.) DM, crude protein, ADF, WSC, ash and ME of $156(25.4) \mathrm{g} \mathrm{kg}^{-1}, 221$ (23.5) $\mathrm{g} \mathrm{kg}^{-1} \mathrm{DM}, 237$ (12.2) $\mathrm{g} \mathrm{kg}^{-1} \mathrm{DM}, 141$ (32.6) $\mathrm{g} \mathrm{kg}^{-1} \mathrm{DM}, 83$ (9.9) $\mathrm{g} \mathrm{kg}^{-1} \mathrm{DM}$, and 11.3 (0.30) $\mathrm{MJ} \mathrm{kg}^{-1} \mathrm{DM}$, respectively, while the respective values for herbage offered with the $6.0 \mathrm{~kg}$ concentrate treatment were 157 (34.0) $\mathrm{g}$ $\mathrm{kg}^{-1}, 188$ (29.1) $\mathrm{g} \mathrm{kg}^{-1} \mathrm{DM}, 243$ (13.8) $\mathrm{g} \mathrm{kg}^{-1} \mathrm{DM}, 161$ (35.0) $\mathrm{g} \mathrm{kg}^{-1} \mathrm{DM}, 82$ (10.8) g kg , and 11.3 (0.30) MJ kg-1 DM. 


\section{AGRICULTURAL AND FOOD SCIENCE}

C.P. Ferris et al. (2020) 29: 130-138

There were no concentrate level $\times$ genotype interactions for any parameter examined in this study $(p>0.05)$, and consequently only the main treatment effects (based on the mean measurements during the three $\mathrm{CH}_{4}$ measurements periods) are presented (Table 1 and 2).

Table 1. Effect of concentrate feed level and cow genotype on feed intake and cow performance (average of the three methane measurement periods)

\begin{tabular}{|c|c|c|c|c|c|c|c|c|}
\hline & \multicolumn{2}{|c|}{$\begin{array}{c}\text { Concentrate level (C) } \\
\qquad\left(\mathrm{kg} \mathrm{d}^{-1}\right)\end{array}$} & \multicolumn{2}{|c|}{ Genotype (G) } & \multirow[b]{2}{*}{ SED } & \multicolumn{3}{|c|}{$p$-value } \\
\hline & 3.0 & 6.0 & $\mathrm{HF}$ & Crossbred & & $\mathrm{C}$ & G & $\mathrm{C} \times \mathrm{G}$ \\
\hline Total DMI (kg d-1 $)$ & 14.9 & 16.0 & 15.6 & 15.3 & 0.66 & 0.077 & 0.561 & 0.695 \\
\hline ME intake (MJ d $\left.{ }^{-1}\right)$ & 173 & 189 & 182 & 179 & 7.6 & 0.030 & 0.548 & 0.691 \\
\hline Milk fat $\left(\mathrm{g} \mathrm{kg}^{-1}\right)$ & 42.2 & 42.1 & 39.4 & 44.9 & 1.41 & 0.930 & $<0.001$ & 0.235 \\
\hline Milk protein $\left(\mathrm{g} \mathrm{kg}^{-1}\right)$ & 35.9 & 34.9 & 34.4 & 36.5 & 0.86 & 0.191 & 0.015 & 0.483 \\
\hline ECM yield (kg d-1) & 20.0 & 22.9 & 21.4 & 21.5 & 1.24 & 0.020 & 0.910 & 0.229 \\
\hline
\end{tabular}

ECM = Energy corrected milk; SED = Standard error of difference; HF = Holstein-Friesian; Crossbreds = Swedish Red $\times($ Jersey $\times$ HolsteinFriesian)

Table 2. Effect of concentrate feed level and cow genotype on methane $(\mathrm{CH} 4)$ emissions from grazing dairy cows (mean of the three $\mathrm{CH} 4$ measurement periods)

\begin{tabular}{|c|c|c|c|c|c|c|c|c|}
\hline & \multicolumn{2}{|c|}{$\begin{array}{c}\text { Concentrate level (C) } \\
\qquad\left(\mathrm{kg} \mathrm{d}^{-1}\right)\end{array}$} & \multicolumn{2}{|c|}{ Genotype (G) } & \multirow[b]{2}{*}{ SED } & \multicolumn{3}{|c|}{$p$-value } \\
\hline & 3.0 & 6.0 & $\mathrm{HF}$ & Crossbred & & $\mathrm{C}$ & G & $C \times G$ \\
\hline $\mathrm{CH}_{4}\left(\mathrm{~g} \mathrm{~d}^{-1}\right)$ & 242 & 255 & 239 & 259 & 10.4 & 0.236 & 0.062 & 0.698 \\
\hline $\mathrm{CH}_{4}$ energy $\left(\mathrm{MJ} \mathrm{d}^{-1}\right)$ & 13.4 & 14.1 & 13.2 & 14.3 & 0.57 & 0.236 & 0.062 & 0.698 \\
\hline $\mathrm{CH}_{4} /$ milk yield $\left(\mathrm{g} \mathrm{kg}^{-1}\right)$ & 12.8 & 11.8 & 11.4 & 13.2 & 0.56 & 0.052 & 0.002 & 0.446 \\
\hline $\mathrm{CH}_{4} / \mathrm{ECM}\left(\mathrm{g} \mathrm{kg}^{-1}\right)$ & 12.4 & 11.4 & 11.6 & 12.3 & 0.50 & 0.041 & 0.130 & 0.155 \\
\hline $\mathrm{CH}_{4} / \mathrm{DM}$ intake $\left(\mathrm{g} \mathrm{kg}^{-1}\right)$ & 16.5 & 16.1 & 15.6 & 17.1 & 0.54 & 0.335 & 0.005 & 0.791 \\
\hline $\mathrm{CH}_{4}-\mathrm{E} / \mathrm{GE}$ intake $\left(\mathrm{MJ} \mathrm{MJ}^{-1}\right)$ & 0.049 & 0.048 & 0.046 & 0.050 & 0.0016 & 0.457 & 0.006 & 0.771 \\
\hline $\mathrm{CH}_{4}-\mathrm{E} / \mathrm{ME}$ intake $\left(\mathrm{MJ} \mathrm{MJ}^{-1}\right)$ & 0.078 & 0.075 & 0.073 & 0.080 & 0.0025 & 0.140 & 0.004 & 0.831 \\
\hline
\end{tabular}

$\mathrm{ECM}=$ Energy corrected milk; SED = Standard error of difference; HF = Holstein-Friesian; Crossbreds = Swedish Red $\times$ (Jersey $\times$ Holstein-Friesian)

While grass DMI was reduced with the $6.0 \mathrm{~kg}$ concentrate treatment $(p=0.037)$, total DMI tended to be higher $(p=0.077)$ and ME intake was higher $(p=0.030)$ with this treatment (Table 1$)$. None of the intake parameters were affected by genotype $(p>0.05)$. Milk yield $(p=0.026)$ and ECM yield $(p=0.020)$ were higher with cows offered the $6.0 \mathrm{~kg}$ concentrate treatment, while milk fat and milk protein content were unaffected $(p>0.05)$ by concentrate level. Similarly, neither BCS nor BW were affected by concentrate level $(p>0.05)$. Neither milk yield nor ECM yield were affected by genotype $(p>0.05)$, while Crossbred cows produced milk with a higher fat $(p<0.001)$ and protein $(p=0.015)$ content than HF cows. Crossbred cows had a higher BCS than HF cows $(p=0.019)$, but had a lower BW $(p=0.027)$. All parameters in Table 1 differed $(p<0.001)$ between periods, with most following normal lactation effects. For example, across period 1, 2 and 3, total DMI (16.3, 15.0, 14.9: standard error of difference $(S E D)=0.33)$, daily milk yield $(26.1,20.5,16.8 ;$ SED $=0.36)$, and $\operatorname{ECM}(28.2,21.0,18.0 ;$ SED $=0.46)$ decreased, while milk fat content $(38.0,42.5,46.0$; SED $=0.77)$, milk protein content $(33.8,35.0,37.4$; SED $=0.73)$ and BW $(509,504,527 ;$ SED $=2.4)$ increased. In contrast, body condition score decreased across periods $1-3(2.44,2.37$ and 2.31; SED $=0.21, p<0.001$ ), while an increase might have been expected. There was a significant genotype $\times$ period interaction for milk fat content, with respective values for periods 1,2 and 3 as follows: HF, 36.6, 39.3 and 


\section{AGRICULTURAL AND FOOD SCIENCE}

C.P. Ferris et al. (2020) 29: 130-138

42.5; Crossbreds, 39.3, 45.8 and 49.5: SED $=1.44, p=0.025$. In addition, there was a significant concentrate level $\times$ period interaction for milk protein content, with respective values for periods 1,2 and 3 as follows; $3.0 \mathrm{~kg}, 33.4$, 35.2 and $39.3 ; 6.0 \mathrm{~kg}, 34.3,34.9$ and $35.5: \mathrm{SED}=1.13, p=0.010$. There were no genotype $\times$ period or concentrate level $\times$ period interactions for any other parameters in Table $1(p>0.05)$.

Increasing concentrate level from 3.0 to $6.0 \mathrm{~kg} / \mathrm{cow}$ per day had no significant effect on $\mathrm{CH}_{4}$ emissions $\left(\mathrm{g}\right.$ day ${ }^{-1}: p=$ $0.236)$, however $\mathrm{CH}_{4}$ emissions per kg milk tended to be lower $(p=0.052)$ while emissions per $\mathrm{kg}$ ECM were lower $\left(p=0.041\right.$ ) with the $6.0 \mathrm{~kg}$ concentrate treatment (Table 2). Emissions per $\mathrm{kg} \mathrm{DMI}, \mathrm{CH}_{4}$ energy/GE intake and $\mathrm{CH}_{4}$ energy/ME intake, were all unaffected by concentrate level $(p>0.05)$. While total $\mathrm{CH}_{4}$ emissions $\left(\mathrm{g}\right.$ day $\left.{ }^{-1}\right)$ tended to be higher with Crossbred cows ( $p=0.062)$, emissions per kg milk were higher $(p=0.002)$, although emissions per $\mathrm{kg}$ ECM did not differ between genotypes $(p>0.05)$. Methane emissions per $\mathrm{kg} \mathrm{DMI}(p=0.005), \mathrm{CH}_{4}$ energy/ GE intake $(p=0.006)$ and $\mathrm{CH}_{4}$ energy/ME intake $(p=0.004)$ were all significantly higher with the Crossbred cows. Across periods 1, 2 and 3, $\mathrm{CH}_{4}$ emissions (g day ${ }^{-1}$ : 269, 247, 230; SED = 5.5, $\left.p<0.001\right), \mathrm{CH}_{4} / \mathrm{DMI}(16.7,16.7,15.6$; SED $=0.46, p=0.037)$ and $\mathrm{CH}_{4} / \mathrm{ME}$ intake $(0.080,0.078,0.072 ; \mathrm{SED}=0.0021 ; p=0.004)$ decreased, while $\mathrm{CH}_{4} /$ GE intake $(0.049,0.049,0.046 ; \mathrm{SED}=0.0014, p=0.099)$ tended to decrease. In contrast, $\mathrm{CH}_{4} / \mathrm{milk}$ yield $(10.6$, $12.3,14.1 ; \mathrm{SED}=0.33, p<0.001)$ and $\mathrm{CH}_{4} / \operatorname{ECM}(10.9,11.9,13.1 ; \mathrm{SED}=0.36, p<0.001)$ increased across periods $1-3$. There were no genotype $\times$ period or concentrate level $\times$ period interactions for any parameter presented in Table $2(p>0.05)$.

\section{Discussion \\ Cow performance}

While the role of crossbreeding has been examined in many studies, few studies have examined the performance of three-breed crossbred dairy cows. Exceptions include studies by Malchiodi et al. (2014) involving Montbeliard $\times$ (Swedish Red $\times$ Holstein-Friesian) cows, Hazel et al. (2013) studying Montbeliard $\times$ (Jersey $\times$ Holstein-Friesian) cows, and Ferris et al. (2018) working with Swedish Red $\times$ (Jersey $\times$ Holstein) cows. Across the three measurement periods in the current study, HF cows produced $1.6 \mathrm{~kg}$ day ${ }^{-1}$ more milk than the Crossbred cows, while the latter produced milk with a significantly higher fat and protein content. The overall effect was that ECM yield was unaffected by genotype, which is largely in agreement with the results of many previous studies evaluating crossbred cows within low-moderate concentrate input systems (Prendiville et al. 2009, Vance et al. 2013, Ferris et al. 2018). The similar yield of milk solids with both genotypes was achieved despite the Crossbreds being, on average, 40 kg lighter than HF cows, and reflects the fact that estimated daily feed intake did not differ between genotypes in the current study. That lighter Crossbreds had similar intakes to Holstein cows has been observed in studies involving both confined (Vance et al. 2012a, 2013) and grazing systems (Prendiville 2009, 2010). Studies involving Jersey $\times$ Holstein crossbred cows have attributed their intake potential to differences in feeding behaviour (Vance 2012b, Prendiville et al. 2009, 2010).

Increasing concentrate intake from 3.0 to $6.0 \mathrm{~kg}$ day ${ }^{-1}$ resulted in a $1.6 \mathrm{~kg} \mathrm{day}^{-1}$ reduction in estimated herbage DM intake, representing a substitution rate of $0.6 \mathrm{~kg}$ herbage DM/ $\mathrm{kg}$ concentrate DM. However, taking account of substitution, each $1 \mathrm{~kg}$ concentrate offered resulted in an additional ME intake of approximately $5.4 \mathrm{MJ} / \mathrm{cow} / \mathrm{day}$, which aligns closely with the mean milk yield response to concentrate feeding observed over the three measurement periods, namely $1.0 \mathrm{~kg}$ milk/kg concentrate.

There was no evidence of a concentrate level $\times$ genotype interaction for any of the milk production variables presented, with this in agreement with a number of previous comparisons of crossbred and Holstein-Friesian cows offered low-medium concentrate levels (Walsh et al. 2008, Vance et al. 2013, Ferris et al. 2018).

\section{Methane production}

Mean $\mathrm{CH}_{4}$ emissions across treatments in this study $\left(12.0 \mathrm{~g} \mathrm{~kg}^{-1} \mathrm{ECM}\right.$ and $\left.16.3 \mathrm{~g} \mathrm{~kg}^{-1} \mathrm{DMI}\right)$ were in line with those recorded in a number of previous $\mathrm{SF}_{6}$ based studies involving Holstein cows grazing temperate pastures, including O'Neill et al. (2011), namely $13.6 \mathrm{~g} \mathrm{CH}_{4} \mathrm{~kg}^{-1} \mathrm{SCM}$ and $18.1 \mathrm{~g} \mathrm{CH}_{4} \mathrm{~kg}^{-1} \mathrm{DMI}$, and Jiao et al. (2014), namely 12.3 $\mathrm{g} \mathrm{CH}_{4} \mathrm{~kg}^{-1} \mathrm{ECM}$ and $\left.18.8 \mathrm{~g} \mathrm{CH}_{4} \mathrm{~kg}^{-1} \mathrm{DMI}\right)$. Nevertheless, higher $\mathrm{CH}_{4}$ emission values have been recorded in other studies, for example, $26.0 \mathrm{~g} \mathrm{~kg}^{-1} \mathrm{SCM}$ and $25.4 \mathrm{~g} \mathrm{~kg}^{-1} \mathrm{DMI}$ (O'Neill et al. 2012), $26.3 \mathrm{~g} \mathrm{~kg}^{-1} \mathrm{milk}^{\prime}$ and $23.0 \mathrm{~g} \mathrm{~kg}^{-1} \mathrm{DMI}$ (Enriquez-Hidalgo et al. 2014) and $19.4 \mathrm{~g} \mathrm{~kg}^{-1}$ milk and $19.5 \mathrm{~g} \mathrm{~kg}^{-1} \mathrm{DMI}$ (Foley et al. 2009), although these studies generally involved lower yielding cows than those in the current study. The high quality herbage grazed within the study, and its associated rapid rate of passage through the digestive system, will undoubtedly have contributed 


\section{AGRICULTURAL AND FOOD SCIENCE}

C.P. Ferris et al. (2020) 29: 130-138

to the low emission values observed. In addition, the loss in BCS observed across periods 1-3 suggests that cows were in negative energy balance for much of this time, and consequently part of the milk produced may have been derived from mobilisation of body tissue reserves, rather than DM intake, leading to lower emissions per kg milk produced. Furthermore, as this BCS loss was not reflected in data on BW change (likely confounded by rumen fill effects), and subsequently not accounted for within the estimation of DM intake, it is possible that intakes were over-estimated, thus reducing calculated emissions $\mathrm{kg}^{-1} \mathrm{DM}$ intake.

\section{Concentrate levels and methane production}

Methane production per kg ECM decreased with concentrate feeding, which agrees with the findings of Jiao et al. (2014), and the reduction in $\mathrm{CH}_{4} \mathrm{~kg}$ per fat corrected milk observed by Lovett et al. (2005). When a large milk yield response to concentrate feeding is achieved, this can simply dilute $\mathrm{CH}_{4}$ per kg milk production, as observed in the current study. However, concentrate supplementation had no effect on $\mathrm{CH}_{4}$ as a proportion of estimated DM intake, in agreement with the results of a number of other studies (Jiao et al. 2014, Muñoz et al. 2015). While DM intake is known to be a key driver of $\mathrm{CH}_{4}$ production, higher concentrate diets are normally associated with an increase in diet quality, and an associated change in rumen fermentation patterns (reviewed by Johnson and Johnson 1995). In addition, concentrate inclusion can increase rumen fermentation rate, with a subsequent reduction in rumen $\mathrm{pH}$, inhibiting growth and activity of methanogens and protozoa (Hegarty 1999). The absence of an effect of concentrate feeding on $\mathrm{CH}_{4} / \mathrm{DMI}$ was reflected in the absence of an effect on $\mathrm{CH}_{4} / \mathrm{GE}$ intake and $\mathrm{CH}_{4} / \mathrm{ME}$ intake.

\section{Genotype and methane production}

While total $\mathrm{CH}_{4}$ emissions were unaffected by genotype $(p>0.05)$, emissions per kg milk were higher with the Crossbred cows. However, this simply reflects the much improved milk composition with the Crossbred cows, and, when emissions were expressed per kg ECM, there were no differences between genotypes. Likewise, Vance et al. (2011) found no difference in emissions (per kg fat plus protein yield) between grazing Holstein-Friesian and Jersey $\times$ Holstein-Friesian cows, while Xue et al. (2011), with the same genotypes (offered silage and concentrates) found no difference in $\mathrm{CH}_{4}$ energy per $\mathrm{MJ}$ milk energy. Thus the results of the current study are in agreement with the findings of previous studies involving crossbred cows, namely that $\mathrm{CH}_{4}$ production per unit of 'composition corrected' milk is unaffected by genotype.

While intakes did not differ between genotypes in the current study, $\mathrm{CH}_{4}$ emissions per $\mathrm{kg} \mathrm{DMI}$ (and as a proportion of GE and ME intake) were greater with the Crossbred cows. This is contrary to the findings of previous studies comparing Holstein and crossbred cows (Vance et al. 2011, grazing: Xue et al. 2011, offered silage), and comparisons between Holstein and other dairy breeds (Münger and Kreuzer 2006). This difference is important as DMI is normally one of the main drivers of $\mathrm{CH}_{4}$ emissions, although a number of mechanisms exist by which $\mathrm{CH}_{4}$ emissions might be increased at a given DMI. For example, it is known that Jersey crossbred cows have a similar mass of reticulo-rumen as HF cows, despite the former's smaller body mass (Beecher et al. 2014), while differences in grazing behaviour (fewer but longer grazing bouts each day, a greater number of grazing bites, and a longer total grazing time each day: Vance et al. 2012b) have been observed with crossbred compared to purebred cows. If either of these differences were to result in an increased rumen retention time, this would likely increase $\mathrm{CH}_{4}$ emission at a given daily intake of DM (Huhtanen et al. 2016). In addition, Shi et al. (2014) have proposed that a longer retention time of digesta in the rumen changes the expression of methanogenesis pathway genes leading to increased $\mathrm{CH}_{4}$ production. Furthermore, it is possible that differences in the rumen microflora between genotypes may have contributed to these differences. For example, it is known that populations of methanogens can differ between different breeds within the same herd (King et al. 2011). However, despite the differences observed in this study, which suggest higher emissions per kg DMI with crossbred cows, it is important to acknowledge that intakes in the current study were derived from production data rather than direct measurements.

\section{Genotype $\times$ concentrate interactions and methane production}

A further objective of this study was to establish if interactions exist between Genotype and Concentrate level, in relation to $\mathrm{CH}_{4}$ production. The results clearly demonstrated that no interactions existed, and that the two genotypes responded similarly to increasing concentrate level. 


\section{Conclusions}

Methane production $\left(\mathrm{g} \mathrm{day}^{-1}\right.$ ) and $\mathrm{CH}_{4}$ production per kg ECM did not differ between Swedish Red $\times(J e r s e y \times \mathrm{Hol}-$ stein Friesian) crossbred cows and Holstein Friesian cows, suggesting that the adoption of Swedish Red genetics do not offer a strategy to reduce direct $\mathrm{CH}_{4}$ emissions. Indeed, $\mathrm{CH}_{4}$ emissions per kg DMI (g day ${ }^{-1}$ ) were higher with the crossbred cows, and it is speculated that this might be due to differences in rumen size, grazing behaviour, or rumen microflora between genotypes.

\section{Acknowledgements}

This work was funded by Department for Environment, Food \& Rural Affairs, the Scottish Government, Department of Agriculture and Rural Development, and the Welsh Government as part of the UK's Agricultural GHG Research Platform project (www.ghgplatform.org.uk). Thanks are due to staff of the Agri-Food and Biosciences Institute (AFBI) Dairy Unit for care of the experimental animals, and to the laboratory staff AFBI Hillsborough for undertaking chemical analyses.

\section{References}

Agnew, R.E., Yan, T., French, J., Kebreab, E. \& Thomas, C. 2004. Energy requirement and supply. In: Thomas, C. (ed). Feed into Milk - a new applied feeding system for dairy cows. Nottingham University Press, Nottingham. p. 11-20.

Beecher, M., Buckley, F., Waters, S.M., Boland, T.M., Enriquez-Hidalgo, D., Deighton, M.H., O’Donovan, M., \& Lewis, E. 2014. Gastrointestinal tract size, total-tract digestibility, and rumen microflora in different dairy cow genotypes. Journal of Dairy Science 97: 3906-2917. https://doi.org/10.3168/jds.2013-7708

Edmonson, A.J., Lean, I.J., Weaver, L.D., Farver, T. \& Webster, G. 1989. A body condition scoring chart for Holstein dairy cows. Journal of Dairy Science 72: 68-78. https://doi.org/10.3168/jds.S0022-0302(89)79081-0

Enriquez-Hidalgo, D., Gilliland, T., Deighton, M.H., O’Donovan, M. \& Hennessy, D. 2014. Milk production and enteric methane emissions by dairy cows grazing fertilized perennial ryegrass pasture with or without inclusion of white clover. Journal of Dairy Science 97: 1400-1412. https://doi.org/10.3168/jds.2013-7034

Ferris, C.P., Gordon, F.J., Patterson, D.C., Mayne, C.S. \& Kilpatrick, D.J. 1999. The influence of dairy cow genetic merit on the direct and residual response to level of concentrate supplementation. Journal of Agricultural Science 132: 467-481. https://doi.org/10.1017/S0021859699006474

Ferris, C.P., Purcell, P.J., Gordon, A.W., Larsen, T. \& Vestergaard, M. 2018. Performance of Holstein and Swedish-Red x Jersey/Holstein crossbred dairy cows within low- and medium-concentrate grassland-based systems. Journal of Dairy Science 101: 72587273. https://doi.org/10.3168/jds.2017-14107

Foley, P.A., Kenny, D.A., Lovett, D.K., Callan, J.J., Boland, T.M. \& O'Mara, F.P. 2009. Effect of DL-malic acid supplementation on feed intake, methane emissions and performance of lactating dairy cows at pasture. Journal of Dairy Science 92: 3258-3264. https://doi.org/10.3168/jds.2008-1633

Gerber, P.J., Steinfeld, H., Henderson, B., Mottet, A., Opio, C., Dijkman, J., Falcucci, A. \& Tempio, G. 2013. Tackling climate change through livestock - A global assessment of emissions and mitigation opportunities. Food and Agriculture Organization of the United Nations (FAO), Rome. http://www.fao.org/3/a-i3437e.pdf

Gordon, F.J., Patterson, D.C., Yan, T., Porter, M.G., Mayne, C.S. \& Unsworth, E.F. 1995. The influence of genetic index for milk production on the response to complete diet feeding and the utilization of energy and nitrogen. Animal Science 61: 199-210. https://doi.org/10.1017/S1357729800013722

Hazel, A.R., Heins, B.J., Seykora, A.J., \& Hansen, L.B. 2013. Montbéliarde-sired crossbreds compared with pure Holsteins for dry matter intake, production, and body traits during the first 150 days of first lactation. Journal of Dairy Science 96: 1915-1923. https://doi.org/10.3168/jds.2012-5667

Hegarty, R.S. 1999. Reducing rumen methane emissions through elimination of rumen protozoa. Australian Journal of Agricultural Research 50: 1321-1327. https://doi.org/10.1071/AR99008

Heringstad, B., Klemetsdal, G. \& Ruane, J. 2000. Selection for mastitis resistance in dairy cattle : a review with focus on the situation in the Nordic countries. Livestock Production Science 64: 95-106. https://doi.org/10.1016/S0301-6226(99)00128-1

Huhtanen, P., Ramin, M. \& Cabezas-Garcia, E.H. 2016. Effects of ruminal digesta retention time on methane emissions: a modelling approach. Animal Production Science 56: 501-506. https://doi.org/10.1071/AN15507

Jiao, H.P., Dale, A.J., Carson, A.F., Murray, S., Gordon, A.W. \& Ferris, C.P. 2014. Effect of concentrate feed level on methane emissions from grazing dairy cows. Journal of Dairy Science 97: 7043-7053. https://doi.org/10.3168/jds.2014-7979

Johnston, K.A. \& Johnston, D.E. 1995. Methane emissions from cattle. Journal of Animal Science 73: 2483-2492. https://doi.org/10.2527/1995.7382483x

Johnston, K.A., Westberg, H.H., Michal, J.J. \& Cossalman, M.W. 2007. The SF6 tracer technique: Methane measurement from ruminants. Springer, New York.

King, E., Smith, R.P., St-Pierre, B. \& Wright, A.-D.G. 2011. Differences in the rumen methanogen populations of lactating Jersey and Holstein dairy cows under the same diet regimen. Applied Environmental Microbiology 77: 5682-5687.

https://doi.org/10.1128/AEM.05130-11 


\section{AGRICULTURAL AND FOOD SCIENCE}

C.P. Ferris et al. (2020) 29: 130-138

Lassey, K.R., Walker, C.F., McMillan, A.M.S. \& Ulyatt, M.J. 2001. On the performance of SF6 permeation tubes used in determining methane emission from grazing livestock. Chemosphere - Global Change Science 3: 367-376. https://doi.org/10.1016/S1465-9972(01)00017-4

Logue, D.N., Offer, J.E. \& Hyslop, J.J. 1994. Relationship of diet, hoof type and locomotion score with leisions of the sole and white line in dairy cattle. Animal Production 59: 173-181. https://doi.org/10.1017/S0003356100007650

Lovett, D.K., Stack, L.J., Lovell, S., Callan, J., Flynn, F., Hawkins, M. \& O’Mara, F.P. 2005. Manipulating enteric methane emissions and animal performance of late-lactation dairy cows through concentrate supplementation at pasture. Journal of Dairy Science 88: 2836-2842. https://doi.org/10.3168/jds.S0022-0302(05)72964-7

Malchiodi, F., Cecchinato, A. \& Bittante, G. 2014. Fertility traits of purebred Holsteins and 2- and 3-breed crossbred heifers and cows obtained from Swedish Red, Montbéliarde, and Brown Swiss sires. Journal of Dairy Science 97: 7916-7926. https://doi.org/10.3168/jds.2014-8156

Münger, A. \& Kreuzer, M. 2006. Methane emission as determined in contrasting dairy cattle breeds over the reproduction cycle. International Congress Series 1293: 119-122. https://doi.org/10.1016/j.ics.2006.01.072

Muñoz, C., Hube, S., Morales, J.M., Yan, T. \& Ungerfeld, E.M. 2015. Effects of concentrate supplementation on enteric methane emissions and milk production of grazing dairy cows. Livestock Science 175: 37-46. https://doi.org/10.1016/j.livsci.2015.02.001

O’Neill, B.F., Deighton, M.H., O'Loughlin, B.M., Mulligan, F.J., Boland, T.M., O'Donovan, M. \& Lewis, E. 2011. Effects of a perennial ryegrass diet or total mixed ration diet offered to spring-calving Holstein-Friesian dairy cows on methane emissions, dry matter intake, and milk production. Journal of Dairy Science 94: 1941-1951. https://doi.org/10.3168/jds.2010-3361

O’Neill, B.F., Deighton, M.H., O'Loughlin, B.M., Galvin, N., O’Donovan, M. \& Lewis, E. 2012 The effects of supplementing grazing dairy cows with partial mixed ration on enteric methane emissions and milk production during mid to late lactation. Journal of Dairy Science 95: 6582-6590. https://doi.org/10.3168/jds.2011-5257

Park, R.S., Agnew, R.E., Gordon, F.J. \& Steen, R.W.J. 1998. The use of near infrared reflectance spectroscopy (NIRS) on undried samples of grass silage to predict chemical composition and digestibility parameters. Animal Feed Science and Technology 72 : 155-167. https://doi.org/10.1016/S0377-8401(97)00175-2

Philipsson, J. \& Lindhe, B. 2003. Experiences of including reproduction and health traits in Scandinavian dairy cattle breeding programmes. Livestock Production Science 83: 99-112. https://doi.org/10.1016/S0301-6226(03)00047-2

Pinares-Patiño, C.S., Ulyatt, M.J., Holmes, C.W., Barry, T.W. \& Lasey, K.R. 2003. Persistence of the between-sheep variation in methane emissions. Journal of Agricultural Science 140: 215-226. https://doi.org/10.1017/S0021859603003071

Prendiville, R., Lewis, E., Pierce, K.M. \& Buckley, F. 2010. Comparative grazing behaviour of lactating Holstein-Friesian, Jersey, and Jersey $\times$ Holstein-Friesian dairy cows and its association with intake capacity and production efficiency. Journal of Dairy Science 93: 764-774. https://doi.org/10.3168/jds.2009-2659

Prendiville, R., Pierce, K.M. \& Buckley, F. 2009. An evaluation of production efficiencies among lactating Holstein-Friesian, Jersey, and Jersey x Holstein-Friesian cows at pasture. Journal of Dairy Science 92: 6176-6185. https://doi.org/10.3168/jds.2009-2292

Purcell, P.J., Law, R.A., Gordon, A.W., McGettrick, S.A. \& Ferris, C.P. 2016. Effect of concentrate feeding method on the performance of dairy cows in early to mid lactation. Journal of Dairy Science 99: 2811-2824. https://doi.org/10.3168/jds.2015-9988

Shi, W., Moon, C.D., Leahy, S.C., Kang, D., Froula, J., Kittelmann, S., Fan, C., Deutsh, S., Cagic, D., Seedorf, H., Kelly, W.J., Atua, R., Sang, C., Soni, P., Li, D., Pinares-Patino, C.S., McEwan, J.S., Janssen, P.H., Chen, F., Visel, A., Wang, Z., Attwood, G.T. \& Rubin, E.M 2014. Methane yield phenotypes linked to differential gene expression in the sheep rumen microbiome. Genome Research 24 : 1517-1525. https://doi.org/10.1101/gr.168245.113

Sørensen, M.K., Norberg, E., Pedersen, J. \& Christensen, L.G. 2008. Crossbreeding in Dairy Cattle : A Danish Perspective. Journal of Dairy Science 91: 4116-4128. https://doi.org/10.3168/jds.2008-1273

Touchberry, R.W. 1992. Crossbreeding effects in dairy cattle: The Illinois experiment, 1949 to 1969. Journal of Dairy Science 75 : 640-667. https://doi.org/10.3168/jds.S0022-0302(92)77801-1

Tyrrell, H.F. \& Reid, J.T. 1965. Prediction of the energy value of cow's milk. Journal of Dairy Science 48: 1215-1223. https://doi.org/10.3168/jds.S0022-0302(65)88430-2

Vance, E.R., Elliott, C.T., Kilpatrick, D.J. \& Ferris, C.P. 2011. Methane production from Holstein-Friesians and Jersey x Holstein-Friesian crossbred dairy cows when managed on a predominantly grazed grass diet. In: Proceedings of 11th British Grassland Society Research Conference, Belfast. p. 129-130.

Vance, E.R., Ferris, C.P., Elliott, C.T., McGettrick, S.A. \& Kilpatrick, D.J. 2012a. Food intake, milk production, and tissue changes of Holstein-Friesian and Jersey $\times$ Holstein-Friesian dairy cows within a medium-input grazing system and a high-input total confinement system. Journal of Dairy Science 95: 1527-1544. https://doi.org/10.3168/jds.2011-4410

Vance, E.R., Ferris, C.P., Elliott, C.T. \& Kilpatrick, D.J. 2012b. A comparison of the feeding and grazing behaviour of primiparous Holstein-Friesian and Jersey $\times$ Holstein-Friesian dairy cows. Irish Journal of Agriculture and Food Research 51: 45-61.

Vance, E.R., Ferris, C.P., Elliott, C.T., Hartley, H.M. \& Kilpatrick, D.J. 2013. Comparison of the performance of Holstein-Friesian and Jersey Holstein-Friesian cross bred dairy cows within three contrasting grassland-based systems of milk production. Livestock Science 151: 66-79. https://doi.org/10.1016/j.livsci.2012.10.011

Walsh, S., Buckley, F., Pierce, K., Byrne, N., Patton, J. \& Dillon, P. 2008. Effects of breed and feeding system on milk production, body weight, body condition score, reproductive performance, and postpartum ovarian function. Journal of Dairy Science 91 4401-4413. https://doi.org/10.3168/jds.2007-0818

Xue, B., Yan, T., Ferris, C.P. \& Mayne, C.S. 2011. Milk production and energetic efficiency of Holstein and Jersey-Holstein crossbred dairy cows offered diets containing grass silage. Journal of Dairy Science 94: 1455-1464. https://doi.org/10.3168/jds.2010-3663

Yan, T., Mayne, C.S., Keady, T.W.J. \& Agnew, R.E. 2006. Effects of dairy cow genotype with two planes of nutrition on energy partitioning between milk and body tissue. Journal of Dairy Science 89: 1031-1042. https://doi.org/10.3168/jds.S0022-0302(06)72170-1 